\title{
Microstructure evolution of $\mathrm{Ti}_{5} \mathrm{Si}_{3}$ in $\mathrm{Cu}-\mathrm{Ti}-\mathrm{Si}$ alloys
}

\author{
${ }^{*}$ Qing Liu ${ }^{1,3}$, Xiao-cui Zhang', Qiang Wang', Wen-zhi Miao ${ }^{1,3}$, Chun-yan Li ${ }^{1,3}$, Hai-min Ding ${ }^{1,3}$ \\ 1. School of Energy, Power and Mechanical Engineering, North China Electric Power University, Baoding 071003, China \\ 2. State Grid Shandong Electric Power Maintenance Company, Jinan 250021, China \\ 3. Hebei Key Laboratory of Electric Machinery Health Maintenance \& Failure Prevention, North China Electric Power University, \\ Baoding 071003, China
}

\begin{abstract}
The Cu-Ti-Si alloys containing in-situ formed $\mathrm{Ti}_{5} \mathrm{Si}_{3}$ are prepared. In order to clarify the $\mathrm{Ti}_{5} \mathrm{Si}_{3}$ formation processes and its microstructure characteristics, the as-cast and deeply etched $\mathrm{Cu}$-Ti-Si alloys with different compositions and cooling rates were investigated using scanning electron microscopy (SEM), transmission electron microscopy (TEM) and X-ray diffraction (XRD). It is found that the eutectic $\mathrm{Ti}_{5} \mathrm{Si}_{3}$ phases in Cu-Ti-Si alloys are rod-like with hexagonal cross section which tend to intertwine with each other to form a firm skeleton like a bird nest structure which can make the alloys keep their original shape even after etching off the Cu matrix. In addition, there is $\mathrm{Cu}$ in the center of many $\mathrm{Ti}_{5} \mathrm{Si}_{3}$ rods, resulting in a core-shell structure. With the increase of the cooling rate, $\mathrm{Ti}_{5} \mathrm{Si}_{3}$ distributes more uniformly, and the diameter of $\mathrm{Ti}_{5} \mathrm{Si}_{3}$ significantly decreases, with a minimum size of less than $100 \mathrm{~nm}$, while the aspect ratio of $\mathrm{Ti}_{5} \mathrm{Si}_{3}$ increases.
\end{abstract}

Key words: microstructures; $\mathrm{Cu}$ alloys; $\mathrm{Ti}_{5} \mathrm{Si}_{3}$; intermetallic compounds

CLC numbers: TG146.1 1

Document code: A

Article ID: 1672-6421(2020)04-286-07

$\mathrm{C}$ opper is widely used due to its high electrical and thermal conductivity, excellent ductility and low cost. However, poor mechanical strength limits its application ${ }^{[-3]}$. One way to improve its mechanical properties is in-situ formation of intermetallic compounds with high melting point, high hardness and modulus by adding alloying elements ${ }^{[4,5]}$. For example, $\mathrm{Cu}-\mathrm{Mn}-\mathrm{Si}$ alloys which are reinforced by $\mathrm{Mn}_{5} \mathrm{Si}_{3}$ have been widely used in mechanical friction parts such as synchronizer rings, self-lubricating bearings and high-speed hydraulic rotors ${ }^{[6-9]}$. Another intermetallic compound, $\mathrm{Ti}_{5} \mathrm{Si}_{3}$, which has similar crystal structure and properties to $\mathrm{Mn}_{5} \mathrm{Si}_{3}{ }^{[10]}$, has been used either as a structural material itself ${ }^{[11-13]}$ or the reinforcement phase in Ti alloys for high temperature applications ${ }^{[14-19]}$ due to its high melting temperature, low density, excellent oxidation resistance, corrosion and creep resistance. However, few researchers have paid attention to the application of $\mathrm{Ti}_{5} \mathrm{Si}_{3}$ in $\mathrm{Cu}$ alloys.

In this work, $\mathrm{Cu}$-Ti-Si alloys containing in-situ formed $\mathrm{Ti}_{5} \mathrm{Si}_{3}$ are prepared. The influences of Ti and Si contents

\section{*Qing Liu}

Female, born in 1986, Ph.D, Lecturer. She has been working in the field of carbon materials and their composites. Her academic research has led to the publication of 18 papers in journals and three invention patents of China.

E-mail: 52452061@ncepu.edu.cn

Received: 2019-12-25; Accepted: 2020-04-26 as well as the cooling rate on the microstructures of $\mathrm{Ti}_{5} \mathrm{Si}_{3}$ are systematically studied. It is considered that the results in this work are meaningful for developing $\mathrm{Cu}$ alloys with $\mathrm{Ti}_{5} \mathrm{Si}_{3}$ intermetallic compound.

\section{Experimental procedure}

$\mathrm{Cu}-\mathrm{Ti}-\mathrm{Si}$ alloys with nominal compositions of $\mathrm{Cu}-$ 1.43Ti-0.5Si, Cu-2.86Ti-1Si and Cu-5.72Ti-2Si (wt.\%) were prepared. Firstly, the electrolytic pure copper was melted in a quartz crucible inside the SPG-20B high frequency induction heating furnace. Then, $\mathrm{Ti}$ and $\mathrm{Si}$ were added into the $\mathrm{Cu}$ melts and held for about $1 \mathrm{~min}$. Finally, the melts were poured into molds to obtain $\mathrm{Cu}$ Ti-Si alloys. The cooling rate was controlled by using the graphite, steel and copper molds with different sizes ( $\Phi 18 \mathrm{~mm}$ and $\Phi 10 \mathrm{~mm}$ ).

The as-cast samples were mechanically grounded and polished by standard routines, and then characterized via a scanning electron microscope (SEM) equipped with an energy-dispersive X-ray spectroscope (EDS) and transmission electron microscope (TEM). Fracture surfaces of the samples were also examined by SEM. In addition, in order to further identify the structure and morphology of $\mathrm{Ti}_{5} \mathrm{Si}_{3}$, the samples were deeply etched using a solution of $10 \% \mathrm{H}_{2} \mathrm{SO}_{4}, 30 \% \mathrm{H}_{2} \mathrm{O}_{2}$ and $60 \%$ water (vol.\%), and $\mathrm{Ti}_{5} \mathrm{Si}_{3}$ was extracted from the 
alloys. The etched samples were investigated by SEM and XRD. The XRD analysis was performed on a Rigaku D/Max $2500 \mathrm{~V}$ diffractometer with $\mathrm{Cu}-\mathrm{K} \alpha$ radiation operated at $40 \mathrm{kV}$, $250 \mathrm{~mA}\left(20^{\circ} \leq 2 \theta \leq 90^{\circ}\right)$.

\section{Results and discussion}

Figure 1 shows the SEM results of the three $\mathrm{Cu}$-Ti-Si alloys prepared by pouring the melt into the graphite molds with a diameter of $10 \mathrm{~mm}$. In Fig. 1(a), a gray phase with an obvious directional distribution can be observed. According to the alloy composition, the gray phase should be a Ti-Si intermetallic compound.
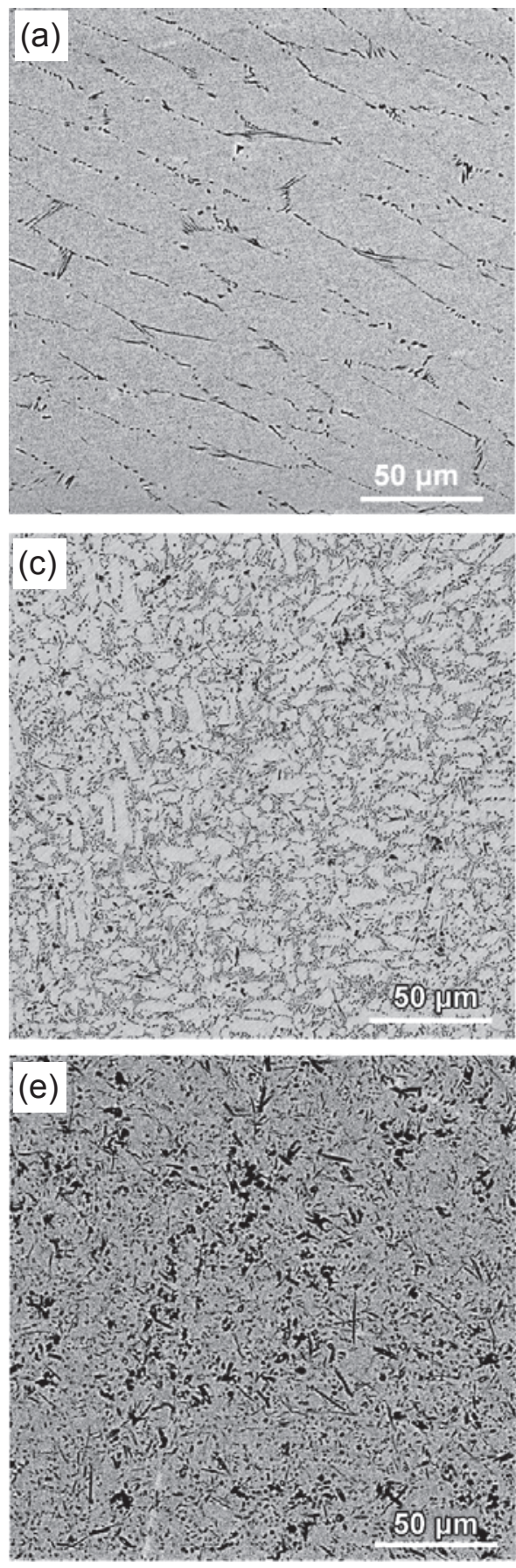

It is known that $\mathrm{Ti}$ and $\mathrm{Si}$ can form various intermetallics such as $\mathrm{TiSi}, \mathrm{TiSi}_{2}, \mathrm{Ti}_{3} \mathrm{Si}_{2} \mathrm{Ti}_{5} \mathrm{Si}_{4}, \mathrm{Ti}_{5} \mathrm{Si}_{3}$, etc ${ }^{[14]}$. In order to accurately determine the Ti-Si intermetallic type, the $\mathrm{Cu}$ matrix was absolutely etched off from the as-cast sample and then the extracted powder was analyzed by XRD. The result is given in Fig. 2(a). It can be found that there are no other intermetallics except $\mathrm{Ti}_{5} \mathrm{Si}_{3}$.

The microstructure of the as-cast $\mathrm{Cu}-2.86 \mathrm{Ti}-1 \mathrm{Si}$ sample is shown in Fig. 1(c). It is obvious that more Ti-Si phases are present, and according to the XRD result given in Fig. 2(b), the Ti-Si phase is also $\mathrm{Ti}_{5} \mathrm{Si}_{3}$. However, compared with the $\mathrm{Ti}_{5} \mathrm{Si}_{3}$ in $\mathrm{Cu}-1.43 \mathrm{Ti}-0.5 \mathrm{Si}$ alloy, the $\mathrm{Ti}_{5} \mathrm{Si}_{3}$ in $\mathrm{Cu}-2.86 \mathrm{Ti}-1 \mathrm{Si}$ is not directional but more uniformly distributed. The EDS mapping
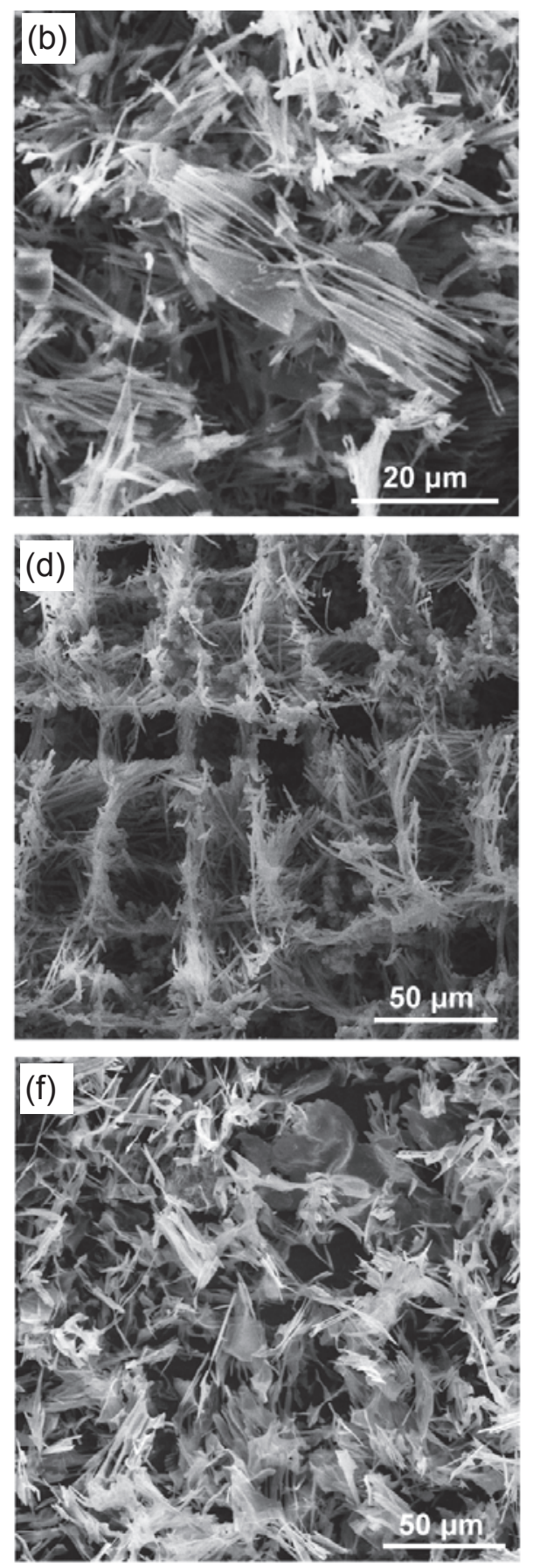

Fig. 1: Microstructures of different samples by graphite molds with a diameter of $10 \mathrm{~mm}$ before (a, $c$ and $e)$ and after (b, d and f) deep etching: (a, b) Cu-1.43Ti-0.5Si; (c, d) Cu-2.86Ti-1Si; (e, f) Cu-5.72Ti-2Si 


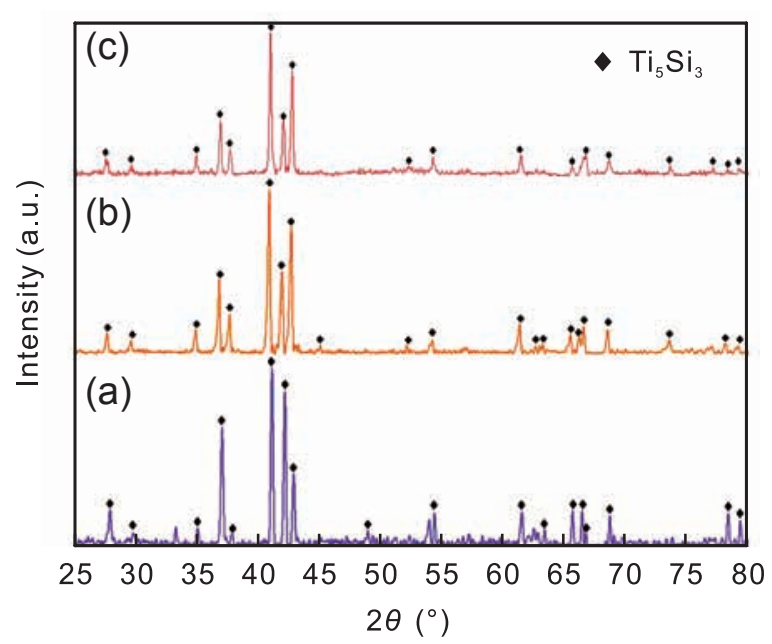

Fig. 2: XRD patterns of exacted powders from different as-cast samples: (a) Cu-1.43Ti-0.5Si; (b) Cu-2.86Ti-1Si; (c) Cu-5.72Ti-2Si
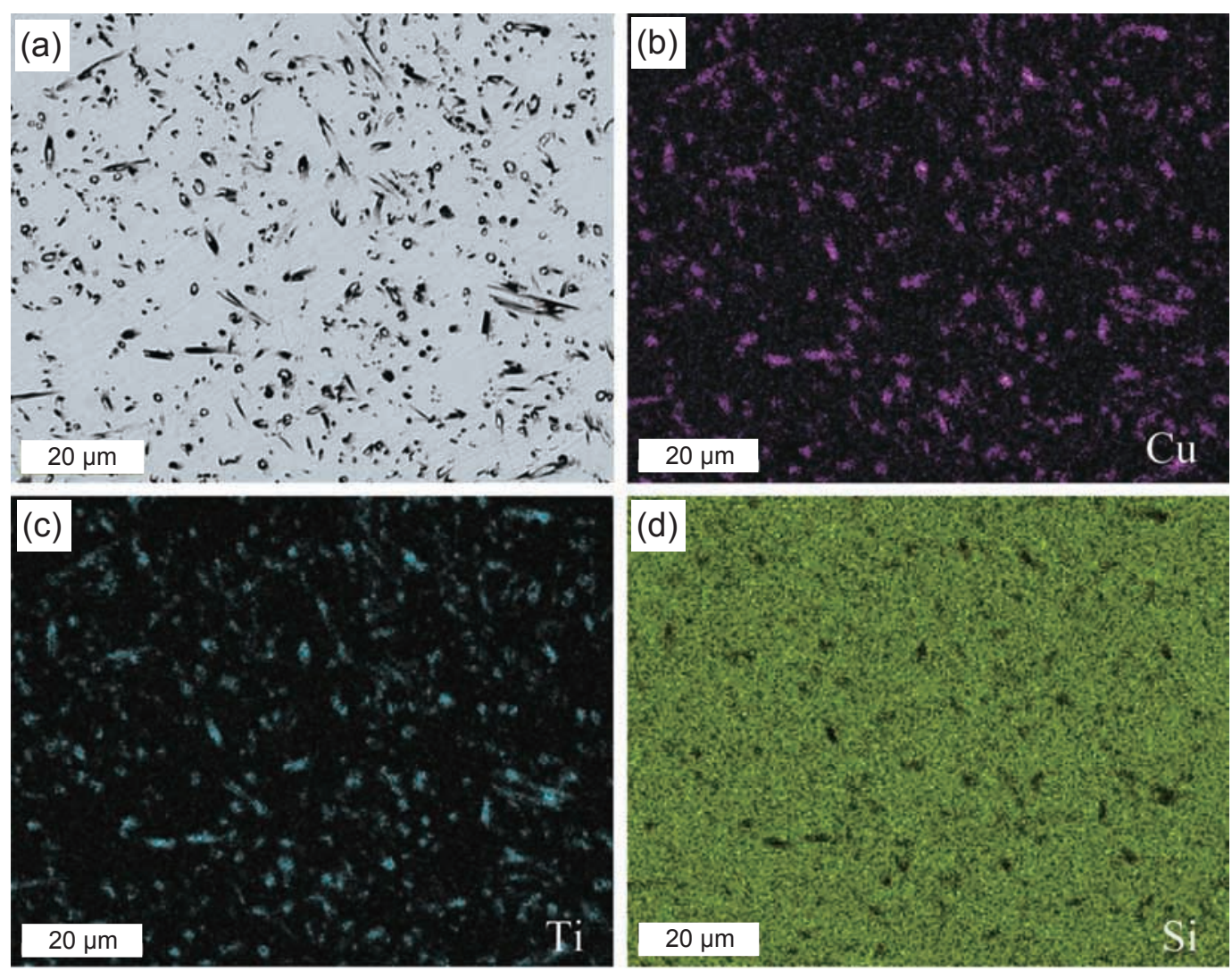

Fig. 3: EDS mapping of as-cast Cu-2.86Ti-1Si: (a) SEM image; (b-d) mapping micrographs for $\mathrm{Cu}, \mathrm{Ti}$ and Si elements

According to Ti-Si phase diagram ${ }^{[20,21]}$ and the microstructure characteristics of the alloys mentioned above, it can be deduced that $\mathrm{Ti}_{5} \mathrm{Si}_{3}$ in the $\mathrm{Cu}-1.43 \mathrm{Ti}-0.5 \mathrm{Si}$ and $\mathrm{Cu}-2.86 \mathrm{Ti}-1 \mathrm{Si}$ alloys are formed by the eutectic reaction. While in the $\mathrm{Cu}-5.72 \mathrm{Ti}-2 \mathrm{Si}$ alloys, besides eutectic $\mathrm{Ti}_{5} \mathrm{Si}_{3}$, some primary $\mathrm{Ti}_{5} \mathrm{Si}_{3}$ phases are also formed.

Figures 1(b), (d) and (f) show the microstructures of $\mathrm{Ti}_{5} \mathrm{Si}_{3}$ extracted from the samples. It can be more obviously seen that the eutectic $\mathrm{Ti}_{5} \mathrm{Si}_{3}$ phase actually grows into a rod shape, and then gathers to bundles with obvious directionality in $\mathrm{Cu}-$ 1.43Ti-0.5Si. In $\mathrm{Cu}-2.86 \mathrm{Ti}-1 \mathrm{Si}$, the rod-like eutectic $\mathrm{Ti}_{5} \mathrm{Si}_{3}$ is analysis shown in Figs. 3(b)-(d) further confirms the uniform distribution of $\mathrm{Ti}_{5} \mathrm{Si}_{3}$ in $\mathrm{Cu}-2.86 \mathrm{Ti}-1 \mathrm{Si}$.

In addition, it is also noticed that many $\mathrm{Ti}_{5} \mathrm{Si}_{3}$ rods are not formed by a single phase, there is another phase in the center, as shown in Fig. 4(a). The TEM analysis and corresponding EDS point analysis shown in Figs. 4(b), (c) prove that the phase in the $\mathrm{Ti}_{5} \mathrm{Si}_{3}$ center is $\mathrm{Cu}$. It is also found from Figs. 4(a), (b) that the $\mathrm{Ti}_{5} \mathrm{Si}_{3}$ is rod-like with hexagonal cross section, which is similar to the $\mathrm{Mn}_{5} \mathrm{Si}_{3}$ in $\mathrm{Cu}-\mathrm{Mn}-\mathrm{Si}$ alloys ${ }^{[7]}$.

The microstructure shown in Fig. 1(e) demonstrates that with an increase in contents of $\mathrm{Ti}$ and $\mathrm{Si}$, the $\mathrm{Ti}-\mathrm{Si}$ phase aggregates into particles with a larger size, but the XRD result in Fig. 2(c) proves that the Ti-Si phase in $\mathrm{Cu}-5.72 \mathrm{Ti}-2 \mathrm{Si}$ is still $\mathrm{Ti}_{5} \mathrm{Si}_{3}$. In addition, two kinds of morphologies of $\mathrm{Ti}_{5} \mathrm{Si}_{3}$ formed in $\mathrm{Cu}-$ 5.72Ti-2Si: one is rod-like, which is similar to that in $\mathrm{Cu}-2.86 \mathrm{Ti}-$ $1 \mathrm{Si}$, while the other one is block-like with a larger size. interlaced and overlapped on the $\mathrm{Cu}$ matrix to form a structure like the bird nest, as shown in Fig. 1(d), and the particle size and aspect ratio of $\mathrm{Ti}_{5} \mathrm{Si}_{3}$ phase are in a narrower distribution range. It is also noticed from Fig. 5(a) that the $\mathrm{Cu}-2.86 \mathrm{Ti}-1 \mathrm{Si}$ samples still maintain the original shape after etching. This result further demonstrates that the intertwined $\mathrm{Ti}_{5} \mathrm{Si}_{3}$ prevents the sample from collapsing after etching away the $\mathrm{Cu}$ matrix. In addition, in $\mathrm{Cu}-5.72 \mathrm{Ti}-2 \mathrm{Si}$, besides the rod-like $\mathrm{Ti}_{5} \mathrm{Si}_{3}$, some primary $\mathrm{Ti}_{5} \mathrm{Si}_{3}$ phases grow into a large sheet-like structure, as shown in Fig. 1(f). 

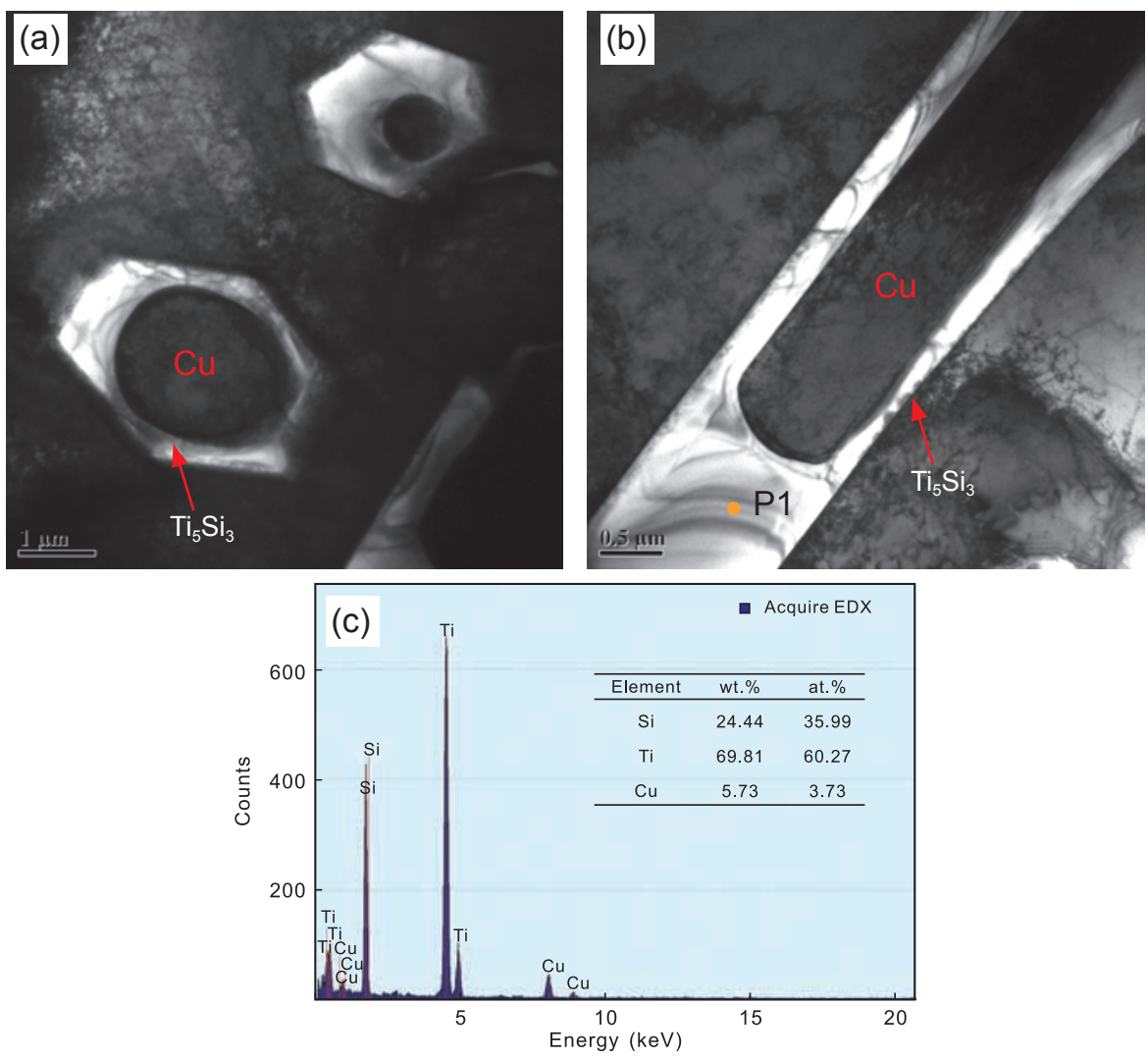

Fig. 4: TEM images of $\mathrm{Ti}_{5} \mathrm{Si}_{3}$ in $\mathrm{Cu}-2.86 \mathrm{Ti}-1 \mathrm{Si}$ : (a) hexagonal cross section; (b) longitudinal section; (c) EDS analysis result of Point P1 shown in Fig. 4b
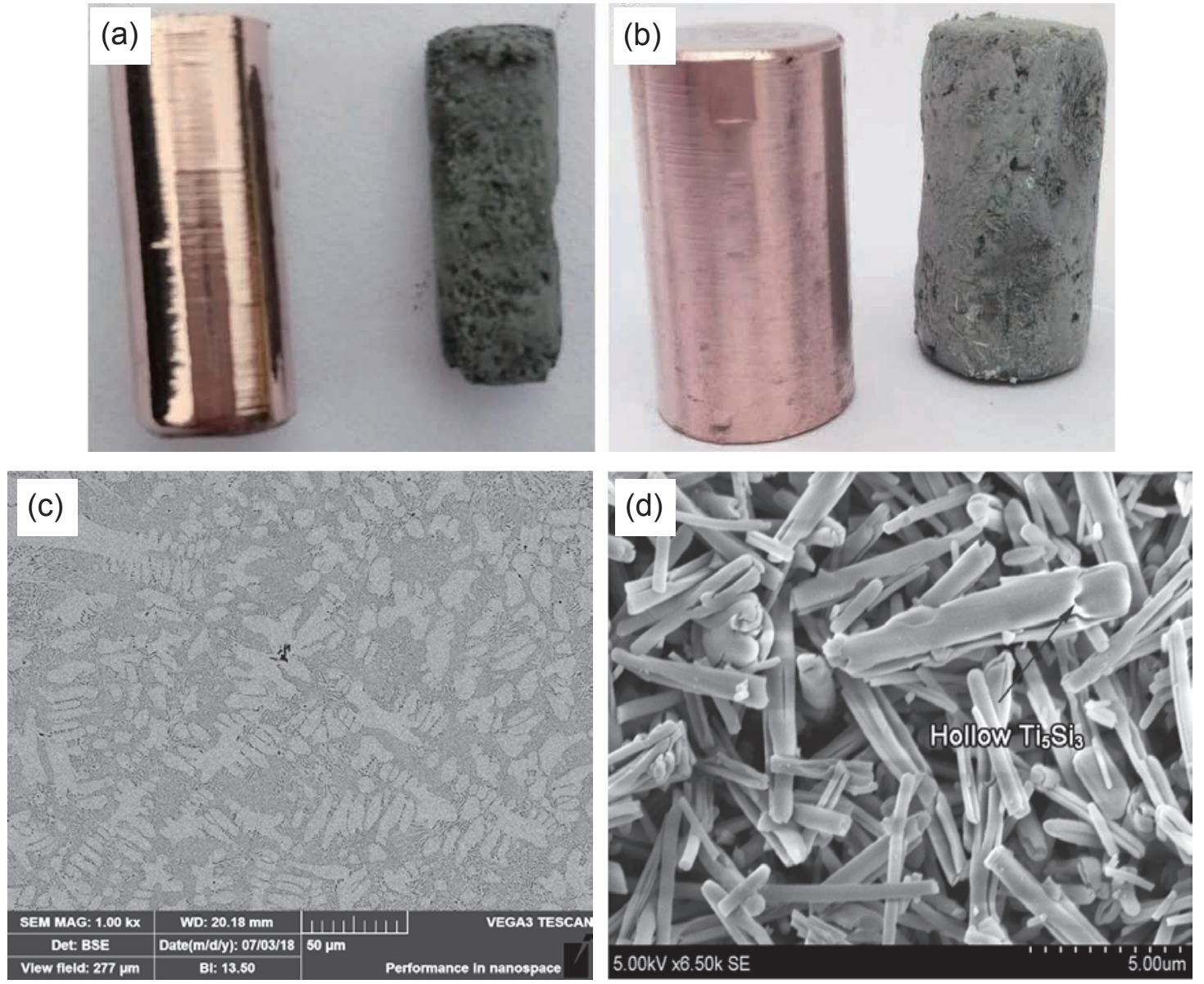

Fig. 5: Cu-2.86Ti-1Si (a) and $\mathrm{Cu}-2.86 \mathrm{Ti}-1 \mathrm{Si}(\mathrm{S})$ (b) samples before and after deep etching, and microstructures of as-cast (c) and deeply etched (d) Cu-2.86Ti-1Si 
The $\mathrm{Cu}-2.86 \mathrm{Ti}-1 \mathrm{Si}$ alloy was then used to investigate the influence of cooling rate on the size, morphology and distribution of $\mathrm{Ti}_{5} \mathrm{Si}_{3}$. The Cu-2.86Ti-1Si melt was poured into the graphite mold with a diameter of $18 \mathrm{~mm}$ in order to decrease the cooling rate, and the obtained sample was designated as $\mathrm{Cu}-$ 2.86Ti-1 Si(S). As shown in Fig. 5(b), Cu-2.86Ti-1Si(S) also maintained its the original shape after etching, which indicates that the $\mathrm{Ti}_{5} \mathrm{Si}_{3}$ is overlapped each other. This can be confirmed by the microstructure shown in Fig. 5(d). The results shown in Figs. 5(c) and (d) also indicate that the microstructures of $\mathrm{Cu}$ 2.86Ti-1Si have been modified by changing the cooling rate. Comparing Fig. 5(d) with Fig. 1(d), the aspect ratio of rod-like $\mathrm{Ti}_{5} \mathrm{Si}_{3}$ is decreased due to the lower cooling rate. Additionally, it can be found that some $\mathrm{Ti}_{5} \mathrm{Si}_{3}$ are hollow rods with hexagonal prisms after etching out the $\mathrm{Cu}$ matrix, which further confirms that $\mathrm{Ti}_{5} \mathrm{Si}_{3}$ is a core-shell structure with $\mathrm{Cu}$ core. In addition, it is also can be seen from Fig. 5(d) that there are many $\mathrm{Ti}_{5} \mathrm{Si}_{3}$ which are rod-like but without $\mathrm{Cu}$ core.

As mentioned above, $\mathrm{Ti}_{5} \mathrm{Si}_{3}$ has a hexagonal structure. The arrangement of Ti and Si atoms along [0001] and [1120] directions is shown in Fig. 6. According to the Hartman-Perdok theory ${ }^{[22]}$, like the growth of $\mathrm{Mn}_{5} \mathrm{Si}_{3}$ reported by $\mathrm{Li}$ et al. ${ }^{[7]}$, the growth direction of $\mathrm{Ti}_{5} \mathrm{Si}_{3}$ crystal is mainly determined by the periodic chain of Ti-Si covalent bond due to the lower binding energy of $\mathrm{Si}-\mathrm{Si}$ or Ti-Ti. As a result, the growth rate along $<11 \overline{2} 0>$ direction on $\{0001\}$ face is higher than other directions due to the complete periodic bond chain of Ti-Si. Moreover, the crystal growth rate along $<0001>$ direction should be higher than that along $<11 \overline{2} 0>$ direction, because the binding energy of Ti-Si bond chain is greater in $<0001>$ direction due to the atomic arrangements with shorter distance. Therefore, $\mathrm{Ti}_{5} \mathrm{Si}_{3}$ will grow into a rod-like hexagonal prism. The reason for the formation of core-shell prisms with $\mathrm{Cu}$ cores is that the diffusion of $\mathrm{Ti}$ and $\mathrm{Si}$ to the inner region of crystal during the growth will become difficult due to the long diffusion distance. As a result, the growth rate of the outside region along the prism $<0001>$ direction is much faster than that of the inner region and then the hollow will be formed in the center of $\mathrm{Ti}_{5} \mathrm{Si}_{3}$. Consequently, $\mathrm{Cu}$ melts will incorporate into the hollow to make $\mathrm{Ti}_{5} \mathrm{Si}_{3}$ transform into core-shell structure with $\mathrm{Cu}$ core.

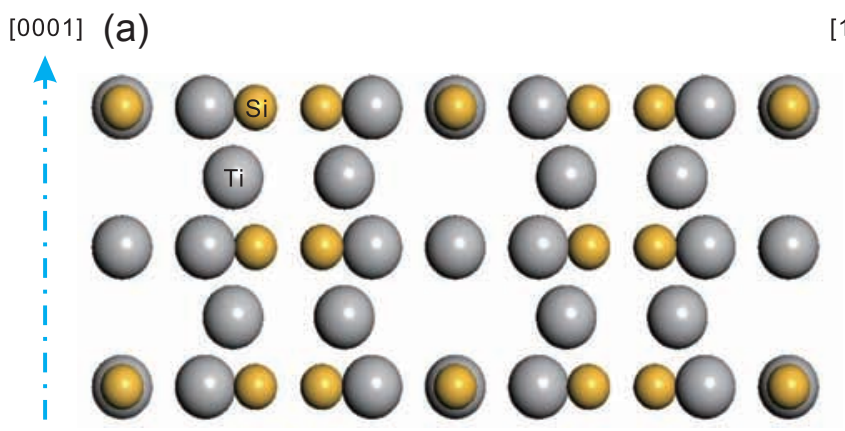

[1120] (b)

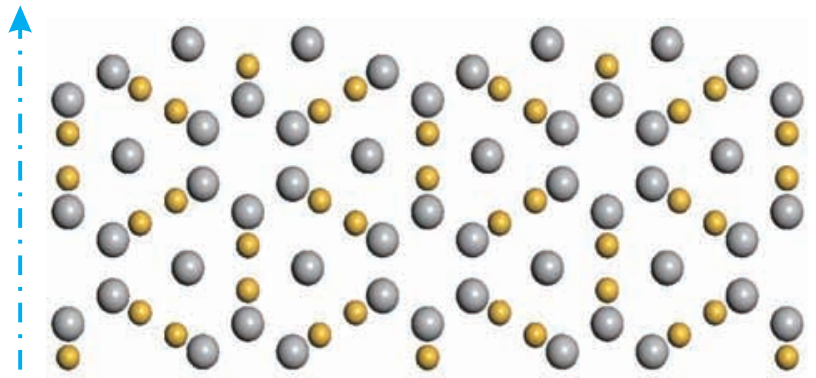

Fig. 6: Atom arrangement in $\mathrm{Ti}_{5} \mathrm{Si}_{3}$ along [0001] (a) and [11 $\left.\overline{2} 0\right]$ (b) direction

The shear fractures of the above prepared $\mathrm{Cu}-2.86 \mathrm{Ti}-1 \mathrm{Si}$ and $\mathrm{Cu}-2.86 \mathrm{Ti}-1 \mathrm{Si}(\mathrm{S})$ samples were also analyzed and the results are shown in Fig. 7. It can be seen from Figs. 7(a), (b), with a lower cooling rate, the cracks propagate along the interface of $\mathrm{Ti}_{5} \mathrm{Si}_{3}$. As a result, many $\mathrm{Ti}_{5} \mathrm{Si}_{3}$ rods or rod bundles are pulled out along the radial direction. In addition, some $\mathrm{Ti}_{5} \mathrm{Si}_{3}$ rods are also pulled out along the axial direction. There are also some large dimples. Therefore, the fracture shown in Figs. 7(a), (b) is a quasi-cleavage fracture. There are more dimples in the fracture surface of the $\mathrm{Cu}-2.86 \mathrm{Ti}-1 \mathrm{Si}$ solidified with a higher cooling rate, as shown in Figs. 7(c), (d), indicating a significant improvement in toughness. Furthermore, it is noticed that most of the $\mathrm{Ti}_{5} \mathrm{Si}_{3}$ rods are also pulled out along the axial direction in this sample, which should be attributed to the improved distribution and lower directionality of $\mathrm{Ti}_{5} \mathrm{Si}_{3}$.

The pullout of $\mathrm{Ti}_{5} \mathrm{Si}_{3}$ is the main mechanism for breakage of the $\mathrm{Cu}-2.86 \mathrm{Ti}-1 \mathrm{Si}$ alloys, so, further increasing the aspect ratio and decreasing the diameter of $\mathrm{Ti}_{5} \mathrm{Si}_{3}$ will be helpful for the property improvement of the alloys, which can be achieved by further increasing the cooling rates. Figure 8 shows the microstructures of the $\mathrm{Ti}_{5} \mathrm{Si}_{3}$ extracted from the $\mathrm{Cu}-2.86 \mathrm{Ti}-1 \mathrm{Si}$ alloys prepared using steel and copper moulds, each with a diameter of $10 \mathrm{~mm}$. As shown in Figs. 8(a), (b), the $\mathrm{Ti}_{5} \mathrm{Si}_{3}$ with a diameter of about $200 \mathrm{~nm}$ and a aspect ratio of greater than 150 is formed in $\mathrm{Cu}-2.86 \mathrm{Ti}-1 \mathrm{Si}$ alloy poured with a steel mould, while the $\mathrm{Ti}_{5} \mathrm{Si}_{3}$ nano wires with a diameter less than $100 \mathrm{~nm}$ could be obtained in the $\mathrm{Cu}-2.86 \mathrm{Ti}-1 \mathrm{Si}$ alloy poured with a copper mould, as shown in Figs. 8(c), (d).

\section{Conclusions}

The microstructures of $\mathrm{Ti}_{5} \mathrm{Si}_{3}$ in the $\mathrm{Cu}$-Ti-Si alloys with different compositions and cooling rates were investigated. The main conclusions are as follows:

(1) The eutectic $\mathrm{Ti}_{5} \mathrm{Si}_{3}$ formed in Cu-Ti-Si alloys is rod-like with a hexagonal cross section which tend to intertwine each other to form a bird nest structure. This structure allows the alloys to maintain their original shape even after etching off the $\mathrm{Cu}$ matrix.

(2) There is $\mathrm{Cu}$ in the center of many $\mathrm{Ti}_{5} \mathrm{Si}_{3}$ rods, which results in the formation of a core-cell structure.

(3) The size, distribution and aspect ratio of $\mathrm{Ti}_{5} \mathrm{Si}_{3}$ are significantly changed with the cooling rates. The diameter of $\mathrm{Ti}_{5} \mathrm{Si}_{3}$ decreases with the increase of the cooling rate, and even 

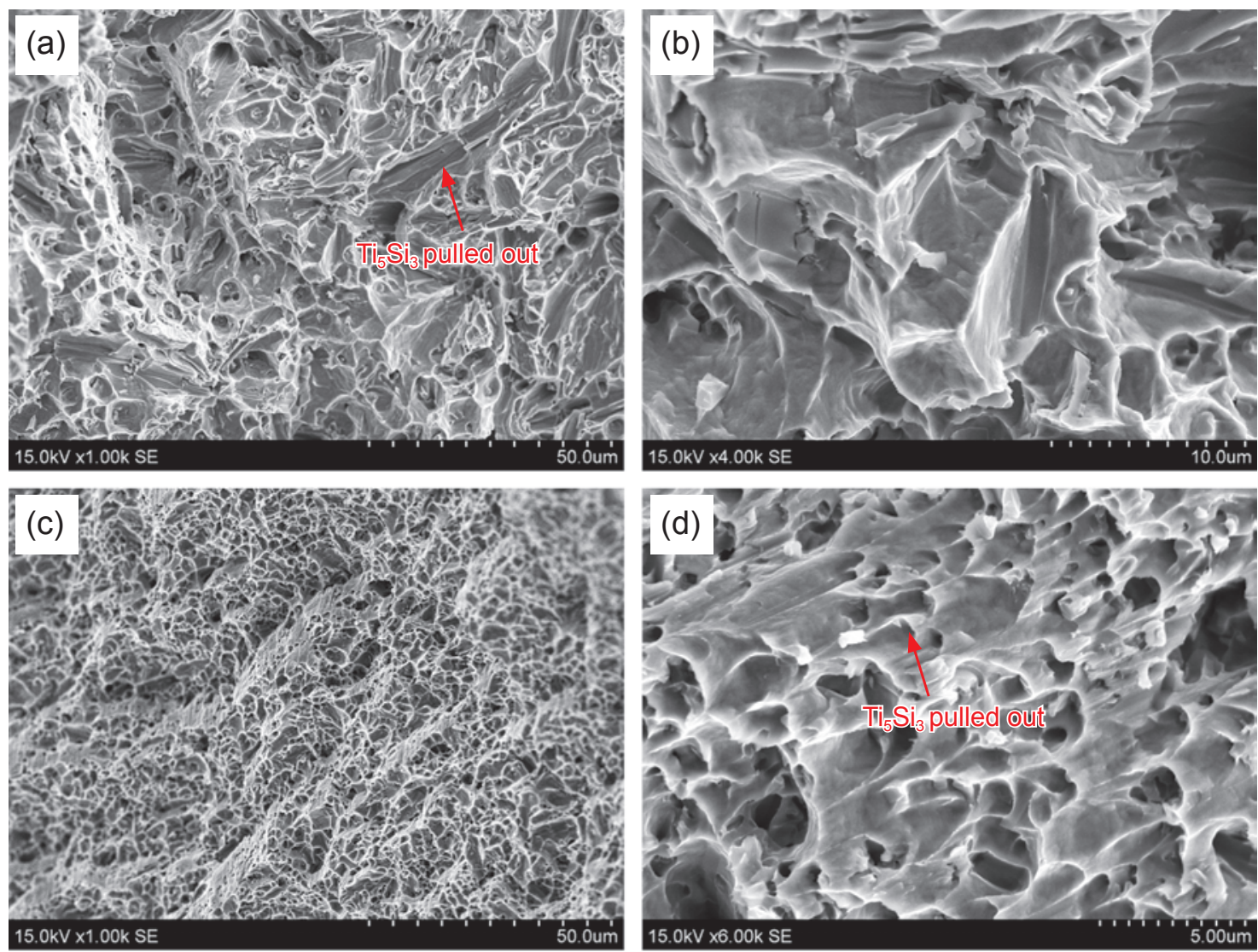

Fig. 7: Fracture microstructures of $\mathrm{Cu}-2.86 \mathrm{Ti}-1 \mathrm{Si}$ samples solidified in graphite mold with diameters of $18 \mathrm{~mm}(\mathrm{a}, \mathrm{b})$ and $10 \mathrm{~mm}(\mathrm{c}, \mathrm{d})$
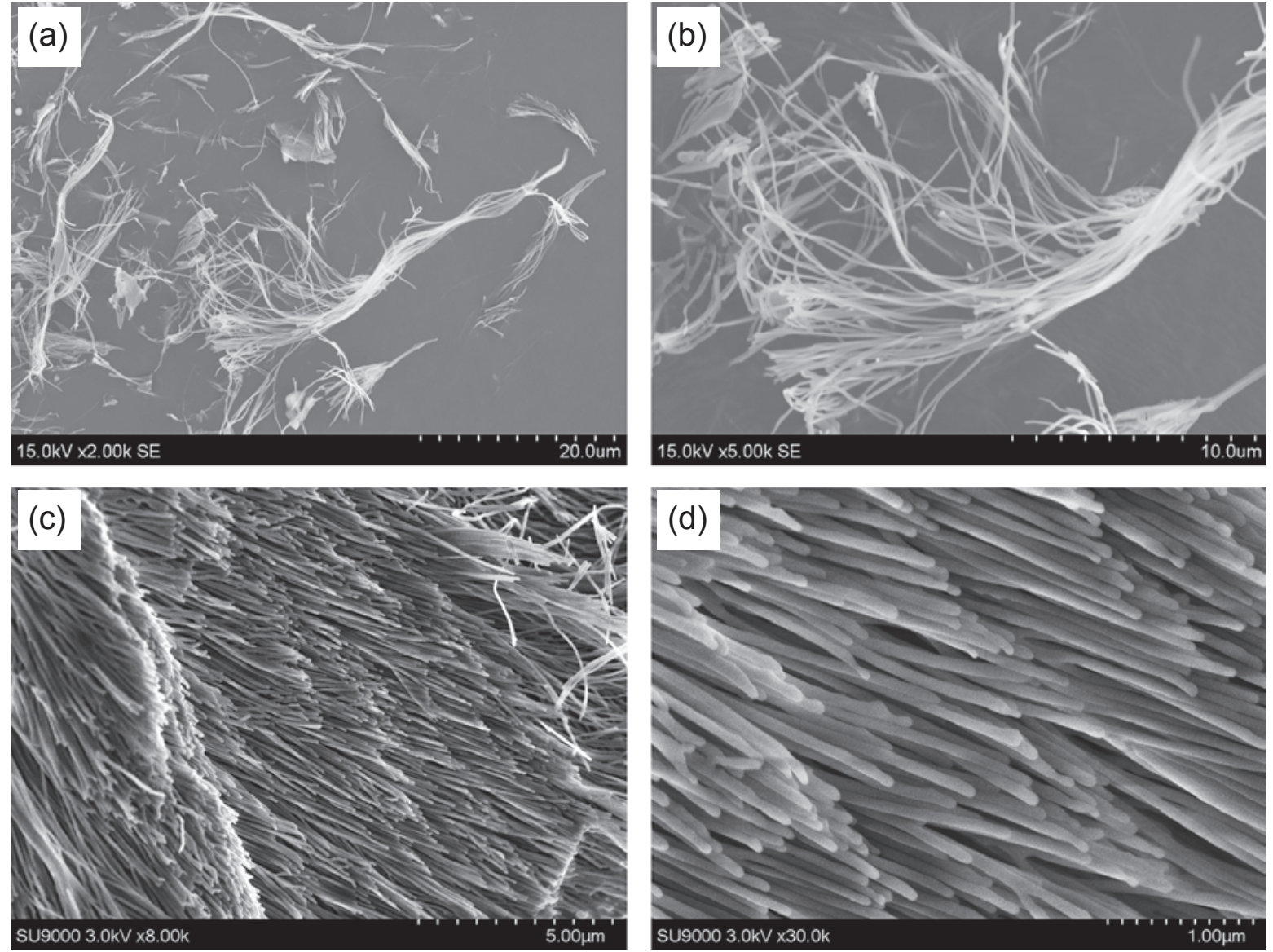

Fig. 8: Microstructures of $\mathrm{Ti}_{5} \mathrm{Si}_{3}$ extracted from different $\mathrm{Cu}-2.86 \mathrm{Ti}-1 \mathrm{Si}$ alloys poured with steel mold (a, b) and copper mold (c, d) with a diameter of $10 \mathrm{~mm}$ 
decreases to less than $100 \mathrm{~nm}$. At the same time, the aspect ratio increases and the distribution is more uniform.

\section{Acknowledgments}

This work was financially supported by the Natural Science Foundation of Hebei Province of China (Grant No. E2019502057) and the Fundamental Research Funds for the Central Universities, China (Grant No. 2018MS120).

\section{References}

[1] Chen F, Ying J, Wang Y, et al. Effects of graphene content on the microstructure and properties of copper matrix composites. Carbon, 2016, 96: 836-842.

[2] Yao G C, Mei Q S, Li J Y, et al. Cu/C composites with a good combination of hardness and electrical conductivity fabricated from $\mathrm{Cu}$ and graphite by accumulative roll-bonding. Materials \& Design, 2016, 110: 124-129

[3] Krishna S C, Jha A K, Pant B, et al. Achieving higher strength in Cu-Ag-Zr alloy by warm/hot rolling. Rare Metals, 2017, 36: 263-267.

[4] Wang W, Li R, Zou C, et al. Effect of direct current pulses on mechanical and electrical properties of aged $\mathrm{Cu}-\mathrm{Cr}-\mathrm{Zr}$ alloys. Materials \& Design, 2016, 92: 135-142.

[5] Fu H, Xu S, Li W, et al. Effect of rolling and aging processes on microstructure and properties of $\mathrm{Cu}-\mathrm{Cr}-\mathrm{Zr}$ alloy. Materials Science Engineering: A, 2017, 700: 107-115.

[6] Mindivan $\mathrm{H}$, Çimenoglu $\mathrm{H}$, Kayali ES. Microstructures and wear properties of brass synchroniser rings. Wear, 2003, 254: 532-537.

[7] Li H, Jie J, Liu S, et al. Crystal growth and morphology evolution of D88 (Mn, $\mathrm{Fe})_{5} \mathrm{Si}_{3}$ phase and its influence on the mechanical and wear properties of brasses. Materials Science Engineering: A, 2017, 704: 45-56.

[8] Li H, Jie J, Zhang P C, et al. Study on the formation and precipitation mechanism of $\mathrm{Mn}_{5} \mathrm{Si}_{3}$ phase in the MBA-2 brass alloy. Metallurgical and Materials Transactions A, 2016, 47: 2616-2624.

[9] Sundberg M, Sundberg R, Hogmark S, et al. Metallographic aspects on wear of special brass. Wear, 1987, 115: 151-165.
[10] Zhang $\mathrm{LN}, \mathrm{Wu} \mathrm{J} \mathrm{Ti}_{5} \mathrm{Si}_{3}$ and $\mathrm{Ti}_{5} \mathrm{Si}_{3}$-based alloys: Alloying behavior, microstructure and mechanical property evaluation. Acta Materialia,1998, 46: 3535-3546.

[11] Shah D M, Berczik D, Anton D L, et al. Appraisal of other silicides as structural materials. Materials Science Engineering: A, 1992, 155: 45-57.

[12] Sandwick T, Rajan K. The oxidation of titanium silicide. Journal of Electronic Materials, 1990, 19: 1193-1199.

[13] Schneibel J H, Rawn C J. Thermal expansion anisotropy of ternary titanium silicides based on $\mathrm{Ti}_{5} \mathrm{Si}_{3}$. Acta Materialia, 2004, 52: 3843-3848.

[14] Colinet C, Tedenac J C. Structural stability of intermetallic phases in the Si-Ti system. Point defects and chemical potentials in D88$\mathrm{Si}_{3} \mathrm{Ti}_{5}$ phase. Intermetallics, 2010, 18(8): 1444-1453.

[15] Schneibel J H, Rawn C J. Thermal expansion anisotropy of ternary titanium silicides based on $\mathrm{Ti}_{5} \mathrm{Si}_{3}$. Acta Materialia, 2004, 52: 3843-3848.

[16] Li Y, Huang S, Bai P, et al. Effect of Ti/Si ratio on the products of laser igniting self-propagating high-temperature synthesis in Cu-Ti-Si system. Journal of Alloys Compound, 2013, 548: 245-248

[17] Kang B Y, Ryoo H S, Hwang W, et al. Explosion synthesis of $\mathrm{Ti}_{5} \mathrm{Si}_{3}-\mathrm{Cu}$ intermetallic compound. Materials Science Engineering: A, 1999, 270: 330-338.

[18] Wang H Y, Lü S J, Zha M, et al. Influence of Cu addition on the self-propagating high-temperature synthesis of $\mathrm{Ti}_{5} \mathrm{Si}_{3}$ in $\mathrm{Cu}-\mathrm{Ti}$ Si system. Materials Chemistry and Physics, 2008, 111(2-3): 463-468.

[19] Lu J W, Zhao Y Q, Du Y, et al. Microstructure and mechanical properties of a novel titanium alloy with homogeneous ( $\mathrm{Ti}$ $\mathrm{Hf})_{5} \mathrm{Si}_{3}$ article-reinforcements. Journal of Alloys and Compound, 2019, 778: 115-123

[20] Ran H S, Niu J N, Song B B, et al. Microstructure and properties of $\mathrm{Ti}_{5} \mathrm{Si}_{3}$-based porous intermetallic compounds fabricated via combustion synthesis. Journal of Alloys and Compound, 2014, 612: 337-342.

[21] Awe O E, Odusote Y A, Hussain L A, et al. Temperature dependence of thermodynamic properties of $\mathrm{Si}$-Ti binary liquid alloys. Thermochimica Acta, 2011, 519: 1-5.

[22] Hartman P, Perdok W G. On the relation between structure and morphology of crystals. Acta Crystallographica, 1955, 8 525-529. 